\title{
WOMEN, TRANSLATION AND CENSORSHIP IN THE FRANCO REGIME
}

\author{
Carmen Camus Camus \\ University of Cantabria
}

\begin{abstract}
This article presents a descriptive study of the incidence of censorship in the translation into Spanish of Larry McMurtry's opera prima Horseman, Pass By. The novel was translated during Fraga Iribarne's term of office at the Ministry of Information and Tourism (1962-1969), a period when the incidence of censorship for the Western genre was at its lowest for the dictatorship. Framed within the temporal borders of the Franco's dictatorship, the study investigates the translation techniques used by Ana M. ${ }^{a}$ de la Fuente when translating violence against women in the discourse of this contemporary Western. The use of violence was one of the censorship criteria followed by the government's officials. This article explores the incidence and effect of censorship and self-censorship in the translation of violence against women in the discourse of the Far West, where violence was part and parcel of the genre.
\end{abstract}

\section{Resumen}

En este artículo se presenta un estudio descriptivo de la incidencia de la censura en la traducción al español de la ópera prima de Larry McMurtry Horseman, Pass By. La traducción de la novela se efectuó durante el mandato de Fraga Iribarne al frente del Ministerio de Información y Turismo (1962-1969), periodo que para el género del Oeste coincide con el de incidencia censoria más baja de la dictadura. Enmarcado en la franja temporal de la dictadura franquista, el estudio investiga las técnicas translémicas utilizadas por Ana M. ${ }^{a}$ de la Fuente al traducir la violencia hacia la mujer en el discurso de este Western contemporáneo. El uso de la violencia fue uno de los criterios censorios aplicados por los censores del ministerio. Este artículo indaga la incidencia y efecto de la censura y autocensura en la traducción de la violencia hacia las mujeres en el discurso del Far West, donde la violencia constituía los mimbres del género. 
Keywords: Translation. Censorship. Western. Gender studies. Violence.

Palabras clave: Traducción. Censura. Género del Oeste. Estudios de género. Violencia 


\section{Introduction}

In the early nineties the publication of Translation, History and Culture (Bassnett and Lefevere 1990) brought about a momentous shift in Translation Studies and laid the foundations for what has proved a fruitful research area which extended the borders of the discipline and incorporated into the new field of investigation cultural factors that until then had been kept outside the realm of the dominant linguistic discourse in the eighties. The Cultural Turn in Translation Studies represented a melting pot which sparked off intense research. In the new paradigm, features of language were not looked into in isolation but in conjunction with those aspects of the culture where they were produced and received.

In their seminal 1990 work, Susan Bassnett and André Lefevere stated:

There is always a context in which the translation takes place, always a history from which the text emerges and into which the text is transposed [...] $[T]$ ranslation as an activity is always doubly contextualized, since the text has a place in two cultures. (Bassnett and Lefevere 1990: 11)

Women's studies, which at the time were expanding along a welter of untrodden trails, found the extended field of translation a fertile ground for research. The cross-disciplinary merging of Women's Studies and Translation has developed into a privileged domain for exploring the cultural impact on gender issues.

Translation practice, translation theory and translation criticism have also been powerfully affected by the focus on gender. As a result of feminist praxis and criticism and the simultaneous emphasis on culture in translation studies, translation has become an important site for the exploration of the cultural impact of gender and the gender-specific influence of culture. With the dismantling of 'universal' meaning and the struggle for women's visibility in feminist work, and with the interest in translation as a visible factor in cultural exchange, the linking of gender and translation has created fertile ground for explorations of influence in writing, rewriting and reading. (Von Flotow 1997) 
Each geographical and cultural context breeds a characteristic cultural product. In the merged scenario of translation and gender issues, translations cannot be examined and interpreted in isolation; they need to be studied within the cultural contexts where they were bred. In this regard, von Flotow points out:

Contexts are of paramount importance when we produce translations, and when we study them; they shape, influence, permit or prohibit certain versions of certain texts at certain times. (Von Flotow 2005: 39)

The current study derives from a larger investigation which attempts to discover the incidence and effects of Franco's censorship in the western genre. The epistemological foundation of the research is the Descriptive Studies paradigm and the study follows the TRACE (Translations Censored) project methodology. ${ }^{1}$ Framed within the temporal borders of the Franco dictatorship (1939-1975), this paper presents a descriptive study of the incidence of censorship and self-censorship in the Spanish translation of Larry McMurtry's Horseman, Pass By, a contemporary Western published in the source culture in 1961 and translated into Spanish by Ana M. ${ }^{a}$ de la Fuente in 1963. The novel portrays the degeneration of the folk-hero and uses the values of the western myths to question the values of contemporary society. The fragment chosen for analysis depicts the rape of Halmea, the black female housekeeper, by the unprincipled Hud. The analysis focuses on the translation of violence against women in the discourse of the Far West, translated by a woman and sieved through the censorship filter. The quantitative and qualitative data provide a glimpse of the effects that censorship and self-censorship impinged on the translation of violence towards women in a narrative where violence was the staple of the genre.

\section{Methods}

Carol Maier in Issues in the Practice of Translating Women's Fiction (1998: 98) establishes three translational approaches to address gender issues with regard to translation practice. In the first of them, the "null strategy", the translator does not feel the need to make explicit in the translation process any

1. TRACE, a research project funded by the Ministry of Science and Innovation (FFI200805479-C02-02/FILO) and carried out by the Universities of the Basque Country, León and Cantabria, aims at describing the translation process that works underwent during Franco's regime, and, at the same time, attempts to discover whether censorial intervention contributed to the creation of a particular translational behaviour in the Spanish literary system. The TRACE members have published numerous articles on translation and censorship: http://www.ehu.es/trace/inicio.html; http://trace.unileon.es/ 
quiescent gender traits. In the second approach, "the feminist approach to woman", there is a deliberate intervention to bring to light or overtranslate any mark of 'woman' implicit in the text. The third postulate, which Maier refers to as "woman-identified", applies to translators who in the translation process either feel themselves to be involved as a woman or work with authors identified as women, and covers a range of degrees of attention to 'woman' in between the two extremes.

In the case of Horseman, Pass By/Hud, the Spanish translation was carried out by Ana M. ${ }^{a}$ de la Fuente, a woman translator working in the context of a dictatorship with specific translation norms, so that the three aforementioned approaches do not fit with the modus operandi she followed in the translation process:

I should say that, on the question of translations, as with everything else, I believe that acting in all of us there was a kind of automatic switch that triggered an unconscious self-censorship. It is difficult to understand now the climate that was breathed at the time. I suppose most people were "domesticated" and we tried to keep our balance on the tightrope of what was authorised by the regime (Ana M. ${ }^{a}$ de la Fuente, personal communication). ${ }^{2}$

\subsection{Procedure of textual analysis}

The textual analysis consists of three parts. The novel and the Spanish translation are first situated in their socio-cultural and political context. The text fragment selected for analysis is then introduced, and this is followed by the quantitative and qualitative microtextual analysis. The microtextual analysis examines the formal, semantic and pragmatic changes in coupled pairs of translation units (Toury 1995: 79). The translation unit (TU) used varies in extension and consists of "replacing" and "replaced" elements so that the "replacing" element constitutes the solution to a translation problem in the "replaced" element. This definition admits a zero "replacing" element (suppression of a word or larger unit) as the solution to a translation problem in the source text. The changes are first classified formally into the following categories: total or partial suppression, defined as the omission of a complete $\mathrm{TU}$, or part of a TU, considered irrelevant or inappropriate for the target

2. Debo decir que, en materia de traducciones, como en todo lo demás, creo que actuaba en todos nosotros una especie de resorte automático que nos inducía a autocensurarnos inconscientemente. Es muy difícil hacer comprender ahora el clima que se respiraba entonces. Supongo que la mayoría de la población estábamos "domesticados" y procurábamos mantener el equilibrio sobre la maroma de lo que autorizaba el régimen (Ana M. ${ }^{a}$ de la Fuente, personal communication: 20/05/2009). 
audience; total or partial addition, that is, the inclusion in the target text of a complete TU, or part of one, containing information not present or explicit in the source text but considered relevant or necessary for the target readers; and modification, that is, any textual change introduced in the target text that produces effects at the semantic and pragmatic levels. These formal changes are subsequently analysed in terms of their semantic shifts. Total and partial suppressions always represent a semantic reduction while total and partial additions represent either an explicitation of content already present in the co-text or an intensification of the meaning through the introduction of new matter. Modifications can be either commutations or neutralisations. Commutations consist of an exchange of semantic concepts, which can intensify meaning, attenuate it, or maintain a similar semantic effect. Neutralisations attenuate meaning in a number of ways: semantic reduction by means of paraphrase, stylistic elevation, usually achieved through euphemism, or refocalisation, whereby the semantic content is reoriented and presented from a different perspective, thus eliminating undesirable effects. Finally, the semantic shifts are analysed and explained pragmatically in relation to general censorship criteria (Gutiérrez Lanza 2000: 420) or are deemed to have no effect in this regard:

1. To favour the postulates of the regime

2. To reduce suggestive, morbid, erotic content

3. To improve the image of one of the characters

4. To limit the form of expression

The aim of this analytical approach is to unveil the preferred translation techniques applied in the self-censorship process in adjusting the selected text to the target culture requirements, with special focus on the attention to 'woman' in the passage.

\section{Horseman, Pass By / Hud in context}

Larry McMurtry's contemporary western Horseman, Pass By / Hud depicts the decline of the mythical West, as reflected by a change from a religious familyrooted essentially rural life to an irreligious, existential, essentially urban way of life. The novel was significantly unlike the popular Westerns which at the time haunted the shelves of American bookstores and libraries. Horseman, Pass By scathingly exposed the materialism of American society, and the contorted convulsions of a confused middle generation, a great many of whom, under the weight of mass communication, were making a permanent move from the soil to the sidewalks. The crude realism of some of the descriptive 
passages of the novel, and the language - "four-letter words came not in a mere sprinkle but almost in a torrent" (Gard 1961) — meant that some critics considered the work offensive, and the book was withdrawn from some university libraries so that students would not be exposed to its coarseness (Reynolds 1989: 117).

In Spain, Hud was published by Plaza \& Janés in a hardbound edition wrapped in an attractive slipcover. Unlike popular westerns, which catered for the mass market, this edition was clearly aimed at a more educated readership that sought quality in their reading. This is implied in the blurb on the back cover, where McMurtry's suggestive almost poetic literary style is compared with the best of Salinger's prose. The Spanish edition was published in 1963, when the ministry responsible for censorship, the Ministry Information and Tourism, was headed by Fraga Iribarne, whose term of office (1962-1969) is considered to have brought a breath of fresh air to the stale political, social and cultural climate. During the first half of his term of office (1962-1965), when compulsory censorship was still in force, the publication of Westerns, which had shown a marked and sustained increase since 1943, reached its peak, with an annual average of 34.2 authorisation requests for the period (Camus 2010: 45). At the same time, the incidence of censorship for the genre declined to its lowest level of $3.9 \%$, compared to the mean rate of $11.3 \%$ for the dictatorship overall (Camus 2010: 48). In this context of impending official censorship, authors, translators and publishers alike, fearing censorial intervention, frequently resorted to self-censorship (Merino 2008; Rabadán 2000).

On going through the compulsory censorship procedure, no suppressions or modifications were registered in the file for Hud (File no. 4866/63). The only incident recorded was a change in the title from El más salvaje entre mil to Hud. This change was probably made at the request of the publishing house in order to profit from the recent release of the homonymous film, starring Paul Newman and Patricia Neal in the leading male and female roles. It can be concluded, therefore, that all the changes and shifts of meaning in the target text were due to the translator's self-censorship (censorship of fear) and introduced to protect the publisher's financial interests.

American pulp Westerns are directed at a mass market and aimed mainly at a male readership, so the themes and topics depicted cater for those readers. Horseman, Pass By owes its title to the last line of the poem by William Butler Yeats Under Ben Bulben, an intertextual reference that serves as the lettre d'introduction of the literary merits of the book. 
The literature of the West inscribes a predominantly masculine world so that the females present in the genre are instrumental to men's lives and tend to fall into stereotypes (Stoeltje 1975, Camus forthcoming). However, the female characters portrayed in Horseman, Pass By differ from those depicted in pulp Westerns. In the novel, McMurtry characterizes Halmea, the main female protagonist, in a way that modifies not only the masculinist slant of the pulp Western but also subverts the genre's traditional dichotomy of Indian/ white females. The juxtaposition of the rape of Halmea and the rape of the land, which sees the erection upon pastureland of oil derricks, allows McMurtry to call into question the system of values in the Texas of the late 1950s and to present the racial, sexual and moral issues for the youthful narrator, Lonnie, to come to terms with.

\section{Text fragment Horseman, Pass By / Hud}

The fragment selected for microtextual analysis corresponds to the passage in which a drunken Hud brutally assaults and rapes Halmea, the housekeeper on the Bannon ranch. The choice of this extract, which was not altered when passing through the official censorship procedure, is of particular interest since it will reveal the degree of permissiveness allowed when dealing with a topic as controversial as a rape in a novel aimed at the general public. Halmea is a black woman whose age and marital status are unknown, and besides attending to the family's domestic affairs, she takes care of Mrs. Bannon, Lonnie's grandmother and Hud's mother. Both Lonnie and Hud are strongly attracted by her. Lonnie's feelings towards Halmea have a double origin: on the one hand, she symbolises maternal love and, on the other, she arouses his adolescent sex drive. For Hud, however, Halmea represents both a work-worn commodity and the object of his lust. Hud's violent wildness manifests itself in seduction, but with Halmea seduction becomes racist sexual assault.

The rape takes place in Halmea's shack, situated a short distance from the Bannons' house and the bunkhouse occupied by the cowhands. Also involved in the scene besides Halmea and Hud are 17-year-old Lonnie, who narrates the episode in the first person, and Jesse, the cowhand, who both go to Halmea's assistance.

Hud, the 35-year-old stepson of Homer Bannon and constantly at odds with the aging family patriarch, is an embittered, unprincipled man devoted to chasing women and pleasure seeking:

Everybody in the county, even Granddad, took a little of Hud's sourness, and nobody felt quite big enough to do anything about it. Granddad kept him on 
partly because he was a stepson, I guess, and partly because, when Hud was interested and cared to be, he was as good as the best and more reckless than the wildest of the thousand wild-ass cowboys in the Texas cattle country. (McMurtry 1961: 8)

In the ST Halmea speaks a variety of black English, an idiolect that McMurtry represents through a kind of phonetic transcription. These features of substandard English, which serve to set Halmea apart from the other characters, are lost in the TT, since the convention was to translate these idiolects and sociolects into the standard variety of Spanish (Camus 2009). The same, therefore, is true of the peculiar features of the speech of the cowboys, consisting of deviations in number agreement, use of ain't and other contractions, such as gonna and wanna, and double negation. The loss of this characterising function of oral language neutralises social differences between the characters and improves the image of some of them, so that the translation may require the use of other compensatory techniques.

\section{Microtextual analysis}

The selected extract corresponds to the third section of chapter 9. The seven pages it occupies contain approximately 200 sentences. In these sentences, the 36 translation units (TUs) in which differences were noted between the TT and the ST are shown in Table 1. The abbreviations in the right-hand column indicate the result of the comparison of the source and target texts for each translation unit (TU). The letters before the colon indicate the formal and semantic categories, as defined in section 2.1: partial addition (PA), total suppression (TS), partial suppression (PS), and modification (M), this formal change having the semantic subcategories of commutation (C), elevation of style (ES), refocalisation (RF), and semantic reduction (SR). The letters after the colon indicate the pragmatic effects: reduce morbid sexual violence $(\mathrm{V})$, promote postulates of the regime (PR), limit form of expression (LF), improve the image of one of the characters (I) plus Halmea ( $\mathrm{Ha})$, Hud $(\mathrm{Hu})$, Jesse (J) and Lonnie (L), or no effect (NE). 
Table 1. Fragment of the novel Horseman, Pass By/Hud: Comparison of TT with ST

\begin{tabular}{|c|c|c|c|}
\hline $\mathrm{TU}$ & Source Text & Target Text & Comparison \\
\hline 1 & $\begin{array}{l}\text { but then I heard it again and I } \\
\text { knew it was Hud. }\end{array}$ & $\begin{array}{l}\text { pero volví a oírlo y comprendí } \\
\text { que Hud andaba haciendo de las } \\
\text { suyas. }\end{array}$ & PA: IHu \\
\hline 2 & $\begin{array}{l}\text { I thought he had been staggering } \\
\text { around drunk. }\end{array}$ & $\begin{array}{l}\text { Pensé que Hud habría estado } \\
\text { andando por los prados borracho }\end{array}$ & PA: IHu \\
\hline 3 & $\begin{array}{l}\text { Then I heard Halmea crying and } \\
\text { trying to say something, }\end{array}$ & $\begin{array}{l}\text { Entonces se oyó gritar a Halmea, } \\
\text { tratando de decir algo } \\
\end{array}$ & MC: IHa \\
\hline 4 & $\begin{array}{l}\text { They were on the bed, and Hud } \\
\text { had wrestled her part way under } \\
\text { him. }\end{array}$ & $\begin{array}{l}\text { Estaban en la cama, y Hud la } \\
\text { tenía debajo. }\end{array}$ & MSR: V+IHa \\
\hline 5 & $\begin{array}{l}\text { He had made her naked from her } \\
\text { feet to her breasts, and he was } \\
\text { laying across her brown twisting } \\
\text { legs, trying to catch her hand. }\end{array}$ & $\begin{array}{l}\text { La había desnudado desde los } \\
\text { pies hasta los senos y, echado } \\
\text { sobre sus piernas morenas, se es- } \\
\text { forzaba por cogerle una mano. }\end{array}$ & MSR: V+IHa \\
\hline 6 & $\begin{array}{l}\text { and I saw that he was grinning } \\
\text { his old wild grin }\end{array}$ & y vi que sonreía con brutalidad & MC: IHu \\
\hline 7 & $\begin{array}{l}\text { He kept shoving at Halmea's } \\
\text { white nightgown, trying to shove } \\
\text { it over her head, but it was all } \\
\text { wadded up around her breasts. }\end{array}$ & $\begin{array}{l}\text { No hacía más que tirar del } \\
\text { blanco camisón de Halmea, para } \\
\text { sacárselo por la cabeza, pero } \\
\text { la prenda se había enganchado } \\
\text { debajo de sus senos. }\end{array}$ & MC: SE \\
\hline 8 & $\begin{array}{l}\text { He smothered her arm against } \\
\text { his chest and brought his hand } \\
\text { over her shoulder and hit her } \\
\text { with the heel of it, hard in the } \\
\text { face, like he might hit a mare }\end{array}$ & $\begin{array}{l}\text { Apretó el brazo de ella contra su } \\
\text { pecho, la sujetó por un hombro } \\
\text { y la golpeó con el dorso de la } \\
\text { mano, como podría golpear a } \\
\text { una yegua. }\end{array}$ & $\begin{array}{l}\text { MC: V } \\
\text { PS: V }\end{array}$ \\
\hline 9 & $\begin{array}{l}\text { He turned her, then, and jammed } \\
\text { his big knee down between her } \\
\text { naked legs, and he laughed. }\end{array}$ & $\begin{array}{l}\text { La obligó a volverse, le dio } \\
\text { un rodillazo entre sus piernas } \\
\text { desnudas y se echó a reír. }\end{array}$ & MSR: V \\
\hline 10 & $\begin{array}{l}\text { and she groaned when he did. } \\
\text { She said, "Oooah," and I shot } \\
\text { the gun. }\end{array}$ & Ella gimió y yo disparé. & MSR: V+IHa \\
\hline 11 & $\begin{array}{l}\text { He rolled off Halmea and I saw } \\
\text { her brown body twist as she } \\
\text { turned toward the wall. }\end{array}$ & $\begin{array}{l}\text { Hud giró sobre sí mismo y vi } \\
\text { que el cuerpo moreno de la } \\
\text { muchacha se doblaba y se volvía } \\
\text { hacia la pared. }\end{array}$ & MSR: V \\
\hline 12 & $\begin{array}{l}\text { but even before I got there Hud } \\
\text { was out and grabbed me, yanked } \\
\text { at the screen and shoved me } \\
\text { inside, into the yellow light. }\end{array}$ & $\begin{array}{l}\text { Pero antes de que pudiese } \\
\text { alcanzarla, Hud había salido y, } \\
\text { cogiéndome por el cuello, me } \\
\text { empujó hacia el interior. }\end{array}$ & $\begin{array}{l}\text { PA: IHu } \\
\text { PS: V }\end{array}$ \\
\hline 13 & $\begin{array}{l}\text { "You little fucker," he said. } \\
\text { "Come in where you can watch } \\
\text { the show." }\end{array}$ & $\begin{array}{l}\text { —PPobre imbécil! Entra a ver el } \\
\text { espectáculo. }\end{array}$ & MES: LF \\
\hline
\end{tabular}




\begin{tabular}{|c|c|c|c|}
\hline 14 & $\begin{array}{l}\text { "Turn over here, nig," Hud said, } \\
\text { grinning; }\end{array}$ & $\begin{array}{l}\text { —Date la vuelta, negra — dijo } \\
\text { Hud. }\end{array}$ & MES: LF \\
\hline 15 & $\begin{array}{l}\text { I sat against the wall, a ringing } \\
\text { like a seashell in my head. }\end{array}$ & Me zumbaban los oídos. & MSR: NE \\
\hline 16 & $\begin{array}{l}\text { But Hud leaned over and slapped } \\
\text { her on the gut with his open } \\
\text { hand }\end{array}$ & $\begin{array}{l}\text { Pero Hud se inclinó y le golpeó } \\
\text { en el estómago }\end{array}$ & $\begin{array}{l}\text { MSR: IHu } \\
\text { MES: LF }\end{array}$ \\
\hline 17 & $\begin{array}{l}\text { and the air whooshed out of her } \\
\text { mouth and he grabbed her other } \\
\text { ankle and pulled her around him } \\
\text { while she tried to get wind. }\end{array}$ & $\begin{array}{l}\text { El aire se escapó por entre los } \\
\text { labios de Halmea. Mientras ella } \\
\text { trataba de recobrar el aliento, } \\
\text { Hud le cogió el otro tobillo y se } \\
\text { rodeó el cuerpo con las piernas } \\
\text { de la muchacha. }\end{array}$ & PA: IHu \\
\hline 18 & $\begin{array}{l}\text { and I could hear her choking } \\
\text { for wind and I could hear Hud's } \\
\text { breath, }\end{array}$ & Oía jadear a Halmea y a Hud & MSR: V+IHa \\
\hline 19 & $\begin{array}{l}\text { "Ain't she a sweet patootie?" he } \\
\text { said. }\end{array}$ & $\begin{array}{l}-i \text { No es un dulce encanto? - } \\
\text { dijo. }\end{array}$ & MES: LF \\
\hline 20 & $\begin{array}{l}\text { I found one hanging over the } \\
\text { lavatory, and dampened it for } \\
\text { her. }\end{array}$ & & TS: IL \\
\hline 21 & $\begin{array}{l}\text { "I'm gonna lose my beer," he } \\
\text { said. }\end{array}$ & —Estoy hecho un lío. & MC: IJ \\
\hline 22 & $\begin{array}{l}\text { She was laying on the bed where } \\
\text { Hud had just had her, her face in } \\
\text { the crook of one arm. }\end{array}$ & $\begin{array}{l}\text { Estaba tendida en la cama, con la } \\
\text { cara entre los brazos. }\end{array}$ & PS: V \\
\hline 23 & $\begin{array}{l}\text { I saw three or four cut places } \\
\text { on her shoulder and side, where } \\
\text { Hud had scratched her in the } \\
\text { scuffle. }\end{array}$ & $\begin{array}{l}\text { Vi que tenía varios cortes, en la } \\
\text { espalda y en el costado, donde } \\
\text { Hud la había arañado. }\end{array}$ & PS: V \\
\hline 24 & $\begin{array}{l}\text { An' drunk don't mean he can } \\
\text { come in an' do dat to somebody." }\end{array}$ & $\begin{array}{l}\text { Un borracho no hubiera podido } \\
\text { hacer eso a nadie. }\end{array}$ & MRF: IHa \\
\hline 25 & $\begin{array}{l}\text { She got another one, but she } \\
\text { couldn't reach the cut on her } \\
\text { back, }\end{array}$ & $\begin{array}{l}\text { Sacó otra, pero no alcanzaba con } \\
\text { la mano los cortes de la espalda. }\end{array}$ & MC: IHa \\
\hline 26 & $\begin{array}{l}\text { I took the rag from her and } \\
\text { daubed it clean, while she held } \\
\text { her nightgown up. }\end{array}$ & $\begin{array}{l}\text { Le quité la toalla de la mano y le } \\
\text { limpié las heridas mientras ella } \\
\text { mantenía el camisón levantado. }\end{array}$ & MC: IHa \\
\hline 27 & $\begin{array}{l}\text { She snorted. "You see him leave } \\
\text { me alone," she said. "He leave } \\
\text { me alone good aftah he done wit' } \\
\text { me." }\end{array}$ & $\begin{array}{l}\text {-Me dejará en paz cuando haya } \\
\text { acabado conmigo. }\end{array}$ & $\begin{array}{l}\text { PS: IHa } \\
\text { MSR: IHa }\end{array}$ \\
\hline 28 & I seen him come in de do'. & & TS: IHa \\
\hline 29 & Dere I is, I knowed it too. & & TS: IHa \\
\hline
\end{tabular}




\begin{tabular}{|c|l|l|l|}
\hline 30 & $\begin{array}{l}\text { "You get along okay, she said, } \\
\text { and it wasn't me, her old honey, } \\
\text { she was saying it to. }\end{array}$ & $\begin{array}{l}\text {-Te arreglarás perfectamente } \\
\text { sin mí. }\end{array}$ & PS: IL \\
\hline 31 & $\begin{array}{l}\text { I kept seeing Halmea stretched } \\
\text { on her bed naked, and Hud } \\
\text { wrestling her under him. }\end{array}$ & $\begin{array}{l}\text { Me parecía estar viendo } \\
\text { continuamente a Halmea tendida } \\
\text { en su cama, desnuda, y a Hud } \\
\text { encima de ella. }\end{array}$ & MRF: V+IHa \\
\hline 32 & $\begin{array}{l}\text { He did it because he wanted to } \\
\text { get her down and job it in her. I } \\
\text { knew he wanted to get Halmea; }\end{array}$ & $\begin{array}{l}\text { Lo había hecho porque deseaba } \\
\text { a Halmea. }\end{array}$ & $\begin{array}{l}\text { MSR: V } \\
\text { MES: LF }\end{array}$ \\
\hline 33 & $\begin{array}{l}\text { I remembered how she was } \\
\text { crying that night he got home } \\
\text { from Temple; how he had caught } \\
\text { her in the kitchen and pinched } \\
\text { her teats. }\end{array}$ & $\begin{array}{l}\text { Recordé cómo la vi llorar } \\
\text { la noche que él y la abuela } \\
\text { volvieron de Temple, y él le } \\
\text { pellizcó un pecho. }\end{array}$ & MES: LF+V \\
\hline 34 & $\begin{array}{l}\text { Watching him screw Halmea, I } \\
\text { should have killed him, }\end{array}$ & $\begin{array}{l}\text { Al verle maltratar a Halmea, le } \\
\text { hubiese matado }\end{array}$ & MES: LF+V \\
\hline 35 & $\begin{array}{l}\text { But now I could only see her } \\
\text { naked, pinned there on the bed, } \\
\text { like a heifer Hud had thrown } \\
\text { down to work over or to splay; }\end{array}$ & $\begin{array}{l}\text { Pero ahora sólo podía verla des- } \\
\text { nuda en la cama, como una vaca } \\
\text { que Hud hubiera derribado para } \\
\text { marcarla. }\end{array}$ & MSR: V+IHa \\
\hline 36 & $\begin{array}{l}\text { I was thinking how I wanted to } \\
\text { do good things for Halmea and } \\
\text { never do a mean thing to her, but } \\
\text { I couldn't get over wanting to } \\
\text { wallow her. }\end{array}$ & $\begin{array}{l}\text { Pensaba en mis buenos deseos } \\
\text { de no hacer daño a Halmea; pero } \\
\text { no podía vencer aquella mala } \\
\text { inclinación. }\end{array}$ & $\begin{array}{l}\text { MES: } \\
\text { LF+V+IL }\end{array}$ \\
\hline
\end{tabular}

The comparison of the source and target texts yielded a total of 41 changes is 36 TUs (table 2). As can be seen, there is a predominance of neutralising effects (21 instances) plus the semantic reduction effected through partial and total suppressions (9 cases), over intensification (4 partial additions) and commutation of semantic meanings (7 instances), which is consistent with the aim of attenuating a description of rape.

Table 2. Formal and semantic changes in the TT versus the ST

\begin{tabular}{|l|c|l|c|l|c|}
\hline \multicolumn{2}{|c|}{ Formal } & \multicolumn{3}{c|}{ Semantic } \\
\hline Partial addition & 4 & & & Intensification & 4 \\
\hline Modification & 28 & Commutation & 7 & & 7 \\
& & Neutralisation & 21 & Elevation of style & 8 \\
& & & & Refocalisation & 2 \\
& & & Semantic reduction & 11 \\
\hline Partial suppression & 6 & & & Semantic reduction & 6 \\
\hline Total suppression & 3 & & & Semantic reduction & 3 \\
\hline Total & 41 & & & Total & 41 \\
\hline
\end{tabular}


Twenty-three of the changes are related to expressions used to describe sexual violence. At the start of the assault, Hud fights to overcome the resistance offered by Halmea: "Hud had wrestled her part way under him", Hud la tenía debajo, 'Hud had her under him'(UT4); and "he was laying across her brown twisting legs", echado sobre sus piernas morenas, 'lying on her brown legs' (TU5). This resistance is not reflected in the TT, thus reducing the semantic content of the description. At the same time Hud is trying to get his victim's clothes off, but only succeeds in forcing the nightgown as far as her breasts. The TT describes him as tirando, 'pulling', the nightdress to sacarlo, 'pull it', over her head, rather than "shoving", but it gets enganchado, 'caught up' ("wadded up"), on her breasts (TU7). However, these shifts of meaning depict the scene well, with no reduction or intensification of the content. When Hud strikes Halmea - "he brought his hand over her shoulder and hit her with the heel of it, hard in the face", la sujetó por un hombro y la golpeó con el dorso de la mano, "he held her by the shoulder and hit her with the back of his hand' (TU8) - the phrase indicating the force of the blow is suppressed and the manner it is produced is changed. Moreover, in "he jammed his big knee down between her naked legs", le dio un rodillazo entre sus piernas desnudas, 'he kneed her between her naked legs' (TU9), the violence is again attenuated in the TT and the implication of Halmea's resistance is lost. On receiving the blow, "she groaned when he did. She said, 'Oooah'", Halmea's lament is reduced to simply Ella gimió, 'she groaned' (TU10).

Lonnie fires his rifle in an attempt to stop Hud, but the effect is only momentaneous: "He rolled off Halmea", Hud giró sobre sí mismo, 'Hud rolled over' (TU11), where the TT sequence is made innocuous by the suppression of Halmea's presence. Hud's violent behavior is directed at any obstacle that might prevent him from achieving his goal: "Hud was out and grabbed me, yanked at the screen and shoved me inside, into the yellow light". In the ST both Lonnie and the rudimentary door of the shack are objects of Hud's rage. In contrast, in the TT, the descriptive details of the door and the light inside are omitted, although their absence is compensated for through an explicitation of Hud's treatment of Lonnie, which intensifies the violent tone: Hud había salido y, cogiéndome por el cuello, me empujó hacia el interior, 'Hud had come out and, grabbing me by the neck, he pushed me inside' (TU12). Once inside, Hud returns to Halmea and "slapped her on the gut with his open hand", le golpeó en el estómago, 'hit her in the stomach' (TU16). Here the TT does not specify that the blow was produced with the palm of the hand and thus intensifies the violence of the action, although the realism of the description is softened by replacing the vulgar "gut" with the neutral term estómago, 
'stomach'. Hud then consummates the rape: "he grabbed her other ankle and pulled her around him while she tried to get wind", Mientras ella trataba de recobrar el aliento, Hud le cogió el otro tobillo y se rodeó el cuerpo con las piernas de la muchacha, 'While she tried to get wind, Hud grabbed her other ankle and surrounded his body with the girl's legs' (TU17). In this sequence the explicitation added to the verb 'surround' is significant, since it again intensifies the description of the action, which is emphasised still more by moving the subordinate clause to the beginning of the sentence. From the floor, where Hud had knocked him, Lonnie describes the end of the scene: "I could hear her choking for wind and I could hear Hud's breath", where the lexical choice makes a clear distinction between victim and aggressor. However, in the TT their breathing is fused through the use of a single verb: Oia jadear a Halmea $y$ a Hud, 'I could hear Halmea and Hud panting' (TU18).

After Hud has left, Lonnie helps Jesse, who is lying unconscious on the floor, and tries to console Halmea as he tends her wounds: "She was laying on the bed where Hud had just had her, her face in the crook of one arm", Estaba tendida en la cama, con la cara entre los brazos, "She was lying on the bed with her face in her arms' (TU22). Whereas the description in the ST stresses the violence of the crime committed, the TT only reflects Halmea's wretchedness and the injuries she had suffered: "Hud had scratched her in the scuffle", Hud la habia arañado (TU23), but not the resistance offered to her aggressor. Perhaps to compensate, the TT increases the number of cuts on her back: "but she couldn't reach the cut on her back, I took the rag from her and daubed it clean", pero no alcanzaba con la mano los cortes de la espalda. Le quité la toalla de la mano y le limpié las heridas, 'but she couldn't reach the cuts on her back with her hand. I took the towel from her hand and cleaned her wounds' (TU25 y 26).

Lonnie returns to the house and, aware of the breach the incident has opened between him and Halmea, goes to bed mulling over what has happened and remembering the good times they have shared; however, he cannot help recalling the scene he has just witnessed: "I kept seeing Halmea stretched on her bed naked, and Hud wrestling her under him", Me parecía estar viendo continuamente a Halmea tendida en su cama, desnuda, y a Hud encima de ella, 'I seemed to keep seeing Halmea stretched on her bed naked, and Hud on top of her' (TU31). In the ST, the last part of this sequence is very similar to TU4 and again the struggle is omitted in the TT, which accentuates the morbid aspect of the memory. Like Halmea, Lonnie knew that what had happened was inevitable; Hud had not done it because he was drunk: "He did it because he wanted to get her down and job it in her. I knew he wanted to get Halmea", 
Lo había hecho porque deseaba a Halmea, 'He had done it because he desired Halmea' (TU32). In this case, the TT tones down the ST by not alluding to the sexual act and replacing it with the euphemistic desear, 'desire'. Lonnie's thoughts take him back to an earlier episode in which Hud, on returning from Temple, had harassed Halmea: "he had caught her in the kitchen and pinched her teats", y él le pellizcó un pecho, 'and he pinched her breast' (TU33). While the omission of "the kitchen" in the TT is of little significance, the neutralisation of the vulgar expression "teats" with pecho, 'breast', eliminates the association with the cattle world. Moreover, the TT maintains a closer intertextual relation with the earlier episode in chapter 5: "I gave her a little tittie squeeze" (p. 68). Lo único que hice fue darle un pellizquito en el pecho, "All I did was to give her breast a little pinch', where the diminutive, but also vulgar, "tittie" is softened with the neutral term pecho (p. 78).

Lonnie recriminates himself for not having done more to prevent Hud from reaching his goal: "Watching him screw Halmea, I should have killed him", Al verle maltratar a Halmea, le hubiese matado, 'Seeing him ill-treat Halmea, I should have killed him' (TU34), a sequence in which the morbid content is reduced by the euphemism maltratar, which replaces the vulgar "screw". As he tosses and turns in bed, the only thing Lonnie can see is Halmea in that humiliating situation: "But now I could only see her naked, pinned there on the bed, like a heifer Hud had thrown down to work over or to splay", Pero ahora sólo podía verla desnuda en la cama, como una vaca que Hud hubiera derribado para marcarla, 'But now I could only see her naked on the bed, like a cow Hud had thrown down to brand' (TU35). In spite of the slight mitigation introduced by the omission of "pinned" and the reduction of "to work over or to splay" to the verb marcar, 'brand', which only covers a minimal part of the meaning in the ST, the simile leaves not a shadow of doubt concerning the utter cynicism of Hud and the extreme machismo he displays towards women. In the end, what torments Lonnie most is knowing he wanted to do the same: "I was thinking how I wanted to do good things for Halmea and never do a mean thing to her, but I couldn't get over wanting to wallow her", Pensaba en mis buenos deseos de no hacer daño a Halmea; pero no podía vencer aquella mala inclinación, 'I was thinking of my good intentions not to harm Halmea; but I couldn't get over that evil inclination' (TU36). In the TT this feeling remains implicit as "wallow" is replaced by the euphemistic phrase mala inclinación, 'evil inclination'.

As seen in the above analysis, most of the changes in the description of the rape reduce the morbid effect of the sexual violence. At the same time, these semantic shifts and the remaining changes in meaning introduced in the 
TT produce other pragmatic effects in the interpretation of the passage and of the novel as a whole.

Of the four characters involved in the scene, Jesse's image is hardly modified by the changes. This cowhand, who has recently arrived at the ranch and has won over both Lonnie and Halmea, represents the noble side of the prototypical cowboy; as such, he runs to Halmea's assistance but is unable to help her because, no sooner has he entered the shack than Hud knocks him unconscious. Nevertheless, there is one significant commutation in an expression uttered by Jesse when he comes round but is still stunned by the blow: "I'm gonna lose my beer,' he said", -Estoy hecho un lío, 'I'm all confused' (TU21). This change is consistent with the portrayal of Jesse as a noble character, which would be marred if he were suspected of acting under the influence of alcohol.

Hud's image also remains largely unaltered by the changes introduced in the TT. At this stage of the novel his status as the antihero representing the negative side of the cowboy is so well established that the passage only reaffirms this characterisation. Two partial additions to the TT at the beginning of the extract draw the reader's attention to this: "but then I heard it again and I knew it was Hud", pero volví a oirlo y comprendí que Hud andaba haciendo de las suyas, 'but then I heard it again and I knew Hud was up to his tricks again' (TU1); "I thought he had been staggering around drunk...", Pensé que Hud habría estado andando por los prados borracho..., 'I thought that Hud had been walking round the fields drunk...' (TU2). The two additions make explicit Hud's rowdy nature and confirm the impression that the characters depicted as "baddies" can be portrayed as drunkards but the "goodies" cannot. Moreover, a commutation involving intensification serves to emphasise the violent nature of Hud's character: "I saw that he was grinning his old wild grin", $y$ vi que sonreía con brutalidad, 'and I saw he was grinning brutally' (TU6).

Undoubtedly, Halmea is the character that experiences the greatest transformation with the semantic changes introduced in the TT: in four sequences (TU4, 5, 23, 31) the resistance she puts up against her aggressor is eliminated, in another (TU10) her expression of pain is reduced, and in yet another (TU18) her suffering is softened. However, these semantic shifts are offset by other changes. Thus, at the start of the aggression "crying" is commuted to gritar, 'shout' or 'scream': "Then I heard Halmea crying and trying to say something", Entonces se oyó gritar a Halmea, tratando de decir algo, 'Then Halmea was heard to scream, trying to say something' (TU3), which constitutes an intensification of her reaction to the outrage. Later, in the conversation with Lonnie, she confesses that she knew what was going to happen: "I seen 
him come in de do'. Dere I is, I knowed it too" (TU28, 29), words that are suppressed in the TT, since inclusion of these thoughts, together with the omission of her resistance, would have represented an exaggerated attitude of fatalistic submission to Hud's machista aggression. Her image is also modified and further diminished when her condemnation of Hud's behaviour is refocalised in the TT. When Lonnie insinuates that Hud behaved as he did because he was drunk, Halmea rejects drunkenness as a mitigating circumstance, and condemns his conduct as reprehensible itself: "An' drunk don't mean he can come in an' do dat to somebody". In contrast, the TT reads: Un borracho no hubiera podido hacer eso a nadie, 'A drunk couldn't have done that to anyone' (TU24), where Halmea rejects drunkenness as an explanation, but there is no explicit moral condemnation; Hud simply did it because of who and what he is. When Lonnie insists that it will not happen again: "She snorted. 'You see him leave me alone,' she said. 'He leave me alone good aftah he done wit' me"' (TU 27). Her reaction, the animal-like snort, is suppressed in the TT although the same expression is translated in an earlier scene as hizo un mohin de desdén, 'she made a scornful gesture' (McMurtry 1963: 20). In addition, the second part of the sequence is reduced to -Me dejará en paz cuando hay a acabado conmigo, 'He'll leave me alone when he has finished with me', a version that eliminates the reference to Lonnie and, therefore, is less aggressive towards him.

The whole passage is narrated, as is the whole novel, from Lonnie's viewpoint so that any change in the narration not attributed to another character will affect the reader's final impression of the young boy. However, there are four changes that affect Lonnie directly, including the one commented on above that he wanted to do the same as Hud (TU36). Another of less importance occurs when he is still stunned after Hud hit him and feels "a ringing like a seashell in my head", which is rendered less poetically as Me zumbaban los oídos, 'My ears were buzzing' (TU15). The third occurs when Halmea asks him to fetch a damp cloth to revive Jesse: "I found one hanging over the lavatory, and dampened it for her". For some reason, this sequence was suppressed in the TT. It could have been an accidental omission on the part of the translator; on the other hand, she could have considered it unfitting for Lonnie to receive orders from the maid or for him to enter her bathroom, so that this suppression maintains the coherence of Lonnie's image and status as a character.

However, the most significant change concerning Lonnie's image and the interpretation of the novel as a whole is the suppression of the second part of the sequence: "'You get along okay,' she said, and it wasn't me, her old honey, 
she was saying it to.", - Te arreglarás perfectamente sin mí, 'You'll get along perfectly well without me' (TU30). Firstly, the suppressed part marks the end of the almost maternal relationship between Halmea and Lonnie, who from now on will have to fend for himself. Lonnie is no longer the object of her affection, "her old honey", as if Halmea were recriminating him for not having prevented what happened. Secondly, in the context of the novel, the rape is Lonnie's particular rite of passage; he has just entered the adult world. The suppression of this sequence in the TT, and perhaps that of the bathroom, leaves this transformation of Lonnie into an adult implicit in the Spanish version.

Table 3. Distribution of the semantic changes according to the censorship criteria

\begin{tabular}{|l|c|}
\hline \multicolumn{1}{|c|}{ Censorship criteria } & No. of cases \\
\hline Improve the image of a character & 24 \\
\hline Reduce morbid sexual violence & 17 \\
\hline Limit the form of expression & 8 \\
\hline Favour the postulates of the regime & 0 \\
\hline Others not attributable to censorship criteria & 2 \\
\hline Total & 61 \\
\hline
\end{tabular}

Table 3 shows the relationship of the formal and semantic changes with the censorship criteria used in the study. The number of pragmatic effects is 61 , since in some sequences two or more effects have been identified (TU4, 5, $10,18,31,33,34,35,36)$. In two instances (TU7 and 15) the semantic shifts were not considered to have any pragmatic effect. The predominant effect in this passage is to improve the image of one of the characters, mainly Halmea (14 instances), followed by Hud (6 cases), Lonnie ( 3 times) and Jesse ( 1 instance). Since the criteria used are general and in the broader context of our study were applied to both narrative and film, the concept of "improve" should be interpreted as adjusting the character to the prototypes established for the genre and congruent with the ideology of the regime. Thus, the changes involving Hud and Jesse reinforce the stereotypical dichotomy that confronts the "good" and "bad" cowboys. The intensifications in the case of Hud reaffirm him in the role of the "bad guy", as the antihero in this modern Western. In the case of Lonnie the changes prolong the aura of innocence in spite of the violence of the scene he has just witnessed. However, as we have seen in the analysis, it is the image of the female character, Halmea, that is most affected by the cumulative changes. In Hud the suppressions and 
other semantic shifts reduce the resistance and protests Halmea offers in the face of the outrage, converting her practically into the submissive and passive woman, the object of the excesses of machista aggression.

The second most frequent censorship criterion consists in reducing the morbid sexual violence. Of the 23 changes commented on above, 17 reflect this pragmatic effect; by contrast, five instances intensify the violence of the expression and in one commutation (TU7) the exchange of semantic meanings was deemed not to alter the pragmatic effect.

In eight sequences, some of which have already been mentioned in relation to the portrayal of violence, a limitation in the form of expression was noted. Thus, the TT introduces euphemistic formulas or neutral terms to avoid the vulgar "offensive" language or an excessively direct sexual reference: gut > estómago, 'stomach' (TU16); wanted to get her down and job it in her [...] wanted to get her > deseaba a Halmea, 'desired Halmea' (TU32); teats > pecho, 'breast' (TU33); screw > maltratar, 'ill-treat' (TU34); wanting to wallow her > aquella mala inclinación, 'that evil inclination' (TU36).

The three remaining expressions are all uttered by Hud. When he faces Lonnie after the rifle shot, Hud says: "You little fucker", this offensive expression being toned down to -iPobre imbécil!, 'Poor imbecile' (TU13). The second has racist tones and is directed at Halmea: "'Turn over here, nig,' Hud said", —Date la vuelta, negra — dijo Hud, 'Turn over, black girl — said Hud' (TU14), where the Spanish version does not convey such strongly negative connotations as the despective term "nig" does in the ST. The third offensive expression is a comment Hud makes to Lonnie at the end of the rape scene: "'Ain't she a sweet patootie?' he said", where the term patootie can refer either to the slang word butt (buttocks) or the female genitalia, but is considerably softened in the TT: — iNo es un dulce encanto? — dijo, 'Isn't she a sweet charmer? - he said' (TU19).

Table 4 reflects the correspondences between the semantic shifts and the censorship criteria used in the study. The most consistent correspondences $(100 \%)$ are seen for elevation of style (euphemism), which is always associated with limitation of form of expression, partial addition, which in this text serves to adjust Hud's image to that of the prototypical "bad guy", and total suppression of a TU, always linked to improving the image of a character. In fact, all the translation techniques contribute to moulding the characters to the typical profiles for the genre. On the other hand, the reduction techniques (partial suppression and semantic reduction) are those most often used to reduce the morbid violence of the text analysed. 
Table 4. Relation between translation techniques and censorship criteria

\begin{tabular}{|l|l|c|c|}
\hline \multicolumn{2}{|c|}{ Semantic-Pragmatic Correspondences } & No. & $\%$ \\
\hline Modification-Elevation of Style & Limits form of expression & 8 & 100 \\
\hline $\begin{array}{l}\text { Modification-Semantic } \\
\text { Reduction }\end{array}$ & Reduces morbid sexual violence & 8 & 72 \\
\hline $\begin{array}{l}\text { Modification-Semantic } \\
\text { Reduction }\end{array}$ & Improves image of character & 7 & 63 \\
\hline Modification-Commutation & Improves image of character & 5 & 72 \\
\hline Partial Addition & Improves image of character & 4 & 100 \\
\hline Partial Suppression & Reduces morbid sexual violence & 4 & 67 \\
\hline Total Suppression & Improves image of character & 3 & 100 \\
\hline Modification-Elevation of Style & Reduces morbid sexual violence & 3 & 37 \\
\hline Modification-Refocalisation & Improves image of character & 2 & 67 \\
\hline Partial Suppression & Improves image of character & 2 & 33 \\
\hline
\end{tabular}

\section{Discussion}

The analysis indicates that the translator used self-censorship to manipulate the text, moderating the expression of violence in the scene described and attenuating the vulgar and sometimes extremely offensive language. This was indeed confirmed by the translator herself, as was the choice of the use of standard Spanish rather than attempt some kind linguistic characterisation of the sociolects:

If in Hud the vulgar language is somewhat softened it is due, in part, to the fact that at that time it was unusual to see coarse language in print. With regard to the neutralisation of the dialect, this question was a personal decision, since I would not risk putting Manchegan or Andalusian idioms in the mouth of cowboys (Ana M. ${ }^{a}$ de la Fuente, personal communication). ${ }^{3}$

However, as the analysis has shown, the repercussions of the changes introduced in the TT extend far beyond these linguistic modifications.

As we have seen, the translator openly admits that at that time translators exercised self-censorship subconsciously in plying their trade. In Horseman, Pass By/Hud we are dealing with a novel written by McMurtry (a male) and narrated through the eyes of an adolescent Lonnie (a male), in which an episode of rape plays a key role as a "violent assault on Halmea's spirit,

3. Si en Hud se suaviza algo el lenguaje vulgar se debe, en parte, a que en aquel entonces era insólito ver palabras gruesas en letra impresa. En cuanto a lo de neutralizar el dialecto, es cuestión de criterio personal, ya que no me atreví a poner modismos manchegos o andaluces en boca de unos vaqueros (Ana M. ${ }^{a}$ de la Fuente, personal communication: 20/05/2009). 
dignity and body all at once" (Reilly 2000: 41). This has then been transferred into Spanish by a translator (a female) for a predominantly male audience. In his study of the translations of Fanny Hill into Spanish, Santaemilia (2005: 126) identifies three general tendencies in the translation of sex of the female translator in relation to translations carried out by males:

1. Softening or downplaying of sexual references;

2. Desexualization of sexual references.

3. Tendency towards dysphemism and moral censure when women's status is at stake.

The deliberate and unconscious strategies of self-censorship applied by Ana M. ${ }^{a}$ de la Fuente in Hud are largely consistent with these trends but need to be qualified in the context of sexual violence. Most of the softening, which is realized through semantic reductions and suppressions, is related to the violence of the force of the blows struck by Hud and the struggle put up by Halmea rather than the sexual component itself. The desexualization is reflected in the euphemistic descriptions achieved through ambiguous and more general superordinate terms: "fucker" > imbécil; "patootie" > encanto; "job it in" > desear; "screw" > maltratar. More difficult to perceive in the passage analysed is the use of dysphemism and/or moral criticism. Nevertheless, moral criticism is implied in the reference of Hud "being up to his tricks"; the Spanish idiom hacer de las suyas has negative connotations, frequently being associated with delinquency, violence and crime. This prepares the ground for what is to come. The commutation of 'wild' to "brutal grin" also displays a hint of a moral condemnation of Hud's action and character. One further instance of this tendency is the rendering of "wallow" as mala inclinación, "evil inclination', a term that adds clear religious and moral overtones to Lonnie's thoughts as he struggles with his conscience after witnessing the incident.

The translator's use of self-censorship supports Santaemilia's (2005: 121) general axiom that the translation of sex (here sexual violence) is likely to be defensive or conservative, softening sexual references and tending to be more formal than the ST. In the case of Horseman, Pass By/Hud, this "hypercorrection strategy" is also congruent with the "opportunism in translation" suggested by von Flotow (2005: 45); although the publication of Hud took place in a period of relative leniency as regards official censorship, the project was designed to take advantage of the peak popularity of the genre and to coincide with the release of the film. Self-censorship, or the censorship of fear, in this context was applied so as not to jeopardise the financial success 
of the undertaking, which would have suffered if there had been any delay in publication brought about by objections from the official censors.

Inevitably, however, there is a price to pay. The untypical features McMurtry introduced in the characterisation of Halmea were clearly intended to draw attention to the moral issues of racist machismo and to criticize the narrow masculine concept of womanhood in the Texas of the 1950s and in pulp Westerns as a whole. The rape episode is the most significant passage in which Halmea appears and much of McMurtry's characterisation of her is lost in the TT due to the modifications of self-censorship. As a result, the TT serves to reinforce the underlying masculine view rather than to condemn the injustice of feminine subservience, as was McMurtry's intention.

Something similar occurred in the adaptation of the novel for the film. The most significant change was to convert Halmea into a white woman, Al$\mathrm{ma}$, who is separated or divorced from her husband. The rape is toned down to an attempted rape due to the timely intervention of Lonnie. However, by changing the perspective in the film - Lonnie is no longer the narrator-and emphasising the conflict between the old and new West symbolised by Homer Bannon and Hud, the adaptors did not count on the audience's reaction and that Hud's (Paul Newman's) appeal would win the day, thus again thwarting McMurtry's original intention to condemn Hud's lifestyle and total amorality, and creating a mass hero instead:

External graces; he was good with women, he did all those macho things, he wore his pants right, he was a womanizer. But we thought that the fact that he was rotten at the core would be the distinguishable feature. What we didn't realize was that all of the other things overwhelmed that single flaw and he came away a folk hero. Yes they [audiences] couldn't stand the old man, but they love Hud. We just made a mistake. We thought people would turn away from him. He betrayed his neighbors... he would betray anybody, but apparently was a part of the American Dream (Newman 1991, in Jackson 1994: 75).

\section{Conclusion}

The analysis of our data has shown the translator's consistent tendency to make smoother the impact of Hud's sexual assault on Halmea by using a wide range of techniques, to reduce the violence of the passage and, at the same time, to present a tamer and more abnegated woman, in tune with the image of women pursued in the dictatorship. The epitome of Spanish women at the time was of virtuous and suffering women who were expected to emulate the Virgin Mary and concentrate their energies on being good wives and mothers. At the same time, these stoic women, many of whom had reared numerous 
offspring, were supposed to be devoid of sexual appetite and to be at all times subservient to men's sexual drive. All the self-censorship changes introduced by the translator were aimed at reducing the violence of Hud's agression, thus presented him in an improved guise. In the translation of Halmea's response to Hud's brutal sexual aggression, the preferred technique was to curtail the force of her defence, thus softening and reducing the effect of her opposition and in this way making her image comply with that expected for women in the dictatorship at the time the book was published.

\section{References}

BASSNETT, Susan \& André Lefevere (eds.) (1990) Translation, History and Culture. London \& New York: Pinter.

Camus, Carmen. (2009) Traducciones censuradas de novelas y películas del Oeste en la España de Franco. Unpublished PhD. Thesis, Universidad del País Vasco.

Camus, Carmen. (2010) "Censorship in the translations and pseudotranslations of the West". In: Gile, Daniel; Gyde Hansen \& Nike K. Pokorn (eds.) 2010. Why Translation Studies Matters. Amsterdam \& Philadelphia: John Benjamins. pp. 41-56.

Camus, Carmen. (forthcoming) "Western Heroines: Female Stereotypes in the Translations and Pseudotranslations of American Westerns". To appear in Actas del Congreso 'Traducción Textos e Interferencias. Cordoba: Servicio de Publicaciones de la Universidad de Córdoba.

GARD, Wayne. (1961) "Grandfather knew best". New York Times, 18 de junio. p. 27.

GutiÉRrez LanZA, Camino. (2000) Traducción y censura de textos cinematográficos en la España de Franco: Doblaje y subtitulado inglés-español (1951-1975). León: Universidad de León.

JACKSON, Carlton. (1994) Picking up the Tab: The Life and Movies of Martin Ritt. Bowling Green, ON: Bowling Green State University Popular Press.

MAIER, Carol. (1998) "Issues in the Practice of Translating Women's Fiction." Bulletin of Hispanic Studies 75. pp. 95-108.

MCMurTRY, Larry. (1961) Horseman, Pass By. New York: Harper \& Brothers. Cited from the 1985 Popular Library Edition Horseman, Pass By. College Station: Texas A\&M University Press.

MCMURTRY, Larry. (1963) Hud. Barcelona: Plaza \& Janés. Translation by Ana M. ${ }^{a}$ de la Fuente.

MERINO ÁlVAREZ, Raquel (ed.) (2008). Traducción y censura inglés-español: 19391985 Estudios sobre corpus TRACE: cine, narrativa, teatro. Bilbao: Universidad del País Vasco/Universidad de León. 
RABADÁN, Rosa (ed.) (2000). Traducción y censura inglés-español: 1939-1985 Estudio preliminar. León: Universidad de León.

REILly, John M. (2000). Larry McMurtry. A Critical Companion. Westport, Connecticut and London: Greenwood Press.

ReynoldS, Clay (ed.) (1989) Taking Stock: A Larry McMurtry Casebook. Dallas: Southern Methodist University Press.

SantaEmilia, José. (2005) "The Translation of Sex/The Sex of Translation: Fanny Hill in Spanish”. In: Santaemilia, José (ed.) 2005 Gender, Sex and Translation: The Manipulation of Identities. Manchester: St. Jerome. pp. 117-136.

Stoeltje, Beverly J. (1975) "A Helpmate for Man Indeed: The Image of the Frontier Woman." The Journal of American Folklore 88. pp. 25-41.

TRACE Universidad del País Vasco http://www.ehu.es/trace/inicio.html

TRACE Universidad de León http://trace.unileon.es/

TOURY, Gideon. (1995) Descriptive Translation Studies and Beyond. Amsterdam \& Philadephia: John Benjamins.

VON Flotow, Luise. (1997) Translation and Gender: Translating in the 'Era of Feminism'. Manchester: St. Jerome.

VON Flotow, Luise. (2005) "Tracing the context of translation: the example of gender". In: Santaemilia, José (ed.) 2005 Gender, Sex and Translation: The Manipulation of Identities. Manchester: St. Jerome. pp. 39-51. 